\title{
PRINCIPAL COMPONENT ANALYSIS UNTUK SISTEM PENGENALAN WAJAH DENGAN MENGGUNAKAN METODE EIGENFACE
}

\author{
Nunu Kustian \\ Program Studi Teknik Informatika, Universitas Indraprasta PGRI \\ Email: kustiannunu@gmail.com
}

\begin{abstract}
Abstrak
Pengenalan wajah (Face Recognition) adalah merupakan suatu pengenalan pola (pattern recognition) yang khusus untuk kasus wajah. Ini dapat dideskripsikan sebagai pengklasifikasian suatu wajah apakah dikenali (known) atau tidak dikenali (unknown), dimana setelah dibandingkan setelah kemudian disimpan secara tersendiri. Proses pengenalan wajah yang dilakukan oleh komputer tidak semudah dan secepat dibandingkan dengan proses pengenalan yang dilakukan oleh manusia. Manusia dengan mudah dapat mengenali wajah seseorang dengan sangat cepat tanpa rasanya harus berfikir. Input yang diperlukan pada aplikasi ini adalah berupa citra wajah dengan ukuran dan resolusi yang sama. Output aplikasi ini adalah berupa class terdekat dari wajah yang ingin dikenali. Aplikasi ini dibuat menggunakan MATLAB yang cukup handal dan mudah dalam perhitungan matematik dan bekerja dalam konsep matrik serta mempunyai fungsi visualisasi yang bervariasi. Salah satu metode pendekatan yang digunakan adalah Eigenface, sebuah metode yang dikemukakan oleh Turk dan Pentland. Metode ini melibatkan sebuah set wajah yang pada dasarnya melibatkan proses analisis komponen utama (Principal Component Analysis). Dalam metode ini citra wajah akan diproyeksikan dalam sebuah ruang fitur yang menonjolkan variasi yang signifikan di antara citra wajah yang diketahui. Fitur signifikan inilah yang disebut dengan Eigenface karena fitur-fitur tersebut adalah komponen utama dari suatu set citra wajah untuk pelatihan. Hal yang perlu diingat adalah fitur-fitur ini tidak berarti berhubungan dengan fitur-fitur yang terdapat pada wajah, seperti mata, hidung, mulut, dan telinga. Eigenface hanya akan menangkap point-point pada citra yang menyebabkan variasi yang signifikan antara wajah-wajah dalam database yang membuat mereka dapat dibedakan.

Kata Kunci : Eigenface, Citra, Wajah, PCA, Matlab
\end{abstract}

\section{Pendahuluan}

Pengenalan wajah merupakan salah satu pendekatan pengenalan pola untuk keperluan identifikasi personal disamping pendekatan biometrik lainnya seperti pengenalan sidik jari, tanda tangan, retina mata dan sebagainya. Pengenalan citra wajah berhubungan dengan obyek yang tidak pernah sama, karena adanya bagian-bagian yang dapat berubah. Perubahan ini dapat disebabkan oleh ekspresi wajah, intensitas cahaya dan sudut pengambilan gambar, atau perubahan asesoris pada wajah. Dalam kaitan ini, obyek yang sama dengan beberapa perbedaan tersebut harus dikenali sebagai satu obyek yang sama. Secara garis besar metode yang digunakan dalam proses pengenalan wajah ada tiga macam yaitu metode holistik, metode berdasarkan ciri, dan metode hybrid. Diantara metode holistik, metode berdasarkan kenampakan (appearance based- methode) adalah teknik yang sangat sukses untuk pengenalan wajah pada beberapa tahun terakhir ini. Ketika menggunakan metode berdasarkan kenampakan, citra berukuran nxm piksel digambarkan sebagai sebuah vektor dalam ruang yang berdimensi nxm (Rnxm). Dalam praktiknya, ruang yang berdimensi $\mathrm{n} \times \mathrm{m}$ ini terlalu besar untuk melakukan pengenalan citra wajah yang cepat. Untuk memecahkan permasalahan ini biasanya dilakukan dengan menggunakan teknik pereduksian dimensi (Yambor, 2000).

Teknik pereduksian dimensi yang sangat terkenal teknik Eigenfaces yang berorientasi pada metode Principal Component Analysis (Belhumeur, dkk., 1997). PCA yang nantinya akan diintegrasikan dengan teknik pengklasifikasian linier akan sekaligus digunakan pada tahap ekstraksi ciri dalam proses pengenalan citra wajah manusia (Marti, 2007). PCA 
adalah suatu metode ekstraksi ciri atau kompresi data yang mampu mengidentifikasi ciri tertentu yang merupakan karakteristik suatu citra (dalam hal ini adalah wajah).

\section{Tujuan Penelitian}

a. Membangun sebuah perangkat lunak pengenalan citra wajah manusia menggunakan metode Eigenface dengan memanfaatkan GUI dari Matlab.

b. Mempelajari prinsip dasar dari pengenalan wajah dengan menggunakan metode Eigenface.

c. Pada tahap pengujian, akan dicari akurasi atau tingkat pengenalan yang dicapai oleh perangkat lunak ini untuk mengetahui seberapa besar kemampuan dari penerapan metode Eigenface dalam mengenali citra wajah.

\section{Manfaat Penelitian}

a. Dapat mempercepat waktu pencarian informasi seseorang yang mempunyai tingkat kemiripan paling tinggi dengan citra masukan.

b. Sistem aplikasi pencarian informasi seseorang dengan masukan citra wajah.

\section{Tinjauan Pustaka}

Pengenalan wajah adalah suatu metoda pengenalan yang berorientasi pada wajah. Pengenalan ini dapat dibagi menjadi dua bagian yaitu : dikenali atau tidak dikenali, setelah dilakukan perbandingan dengan pola yang sebelumnya disimpan di dalam database. Metoda ini juga harus mampu mengenali objek bukan wajah. Perhitungan model pengenalan wajah memiliki beberapa masalah. Kesulitan muncul ketika wajah direpresentasikan dalam suatu pola yang berisi informasi unik yang membedakan dengan wajah yang lain. Metoda pengenalan wajah memakai dua prosedur, yaitu :

a. Pengenalan kontur wajah dengan mengenali bentuk hidung, mata dan mulut dan bentuk korelasi diantara keduanya.

b. Karakteristik organ tersebut kemudian dinyatakan dalam bentuk vektor Analisis komponen yang prinsipil, berdasarkan informasi dari konsep ini, mencari perhitungan model terbaik yang menjelaskan bentuk wajah dengan mengutip informasi yang paling relevan yang terkandung di dalam wajah tersebut.

Dibalik kemudahan mengenali wajah, ada beberapa masalah yang mungkin timbul dalam proses pengenalan wajah, yaitu: adanya perubahan skala, perubahan posisi, perubahan pencahayaan, atau adanya perubahan detail dan ekspresi wajah.

\section{Metode Eigenface}

Pengenalan Eigenface berasal dari prefiks bahasa Jerman "eigen", yang berarti "sendiri/individual". Metode eigenface dianggap sebagai teknologi pengenalan wajah otomatis pertama yang pernah diciptakan.

Teori ini dikembangkan oleh Turk dan Pentland. Teori ini dikembangakan dengan membagi sebuah citra wajah menjadi data set fitur karakteristik yang disebut eigenface. Fitur karakteristik ini merupakan komponen utama (principal component) dari training set awal dari citra wajah.

Setiap citra wajah dapat dilihat sebagai vektor, jika lebar dan tinggi citra wajah adalah w dan $\mathrm{h}$ piksel, maka jumlah komponen dari vektor tersebut adalah $\mathrm{N}=\mathrm{w} \times \mathrm{h}$. Citra wajah di representasikan sebagai vektor kolom $\mathrm{N}$ dimensi atau matrix $\mathrm{N}$ x 1 .

a. Kalkulasi Eigenface

Algoritma Eigenface pertama-tama dibangkitkan dengan beberapa jumlah dari citra training set. Kemudian citra wajah baru dikenali atau tidak tergantung dari citra pelatihan tersebut. Citra pelatihan tersebut harus memenuhi syarat berikut:

1) Citra wajah dengan ukuran dan format yang sama.

Kita memiliki kumpulan dari citra wajah training set sebanyak M citra wajah dengan lebar dan tinggi berturut-turut $\mathrm{w}$ dan $\mathrm{h}$. Masing-masing citra wajah training set direpresentasikan sebagai vektor kolom dimensi $\mathrm{N}$, dimana $\mathrm{N}=\mathrm{w} \mathrm{x}$ h. Sekumpulan 
citra wajah dalam training set dapat dituliskan sebagai $\mathrm{T}_{\mathrm{i}}=\left\{\mathrm{T}_{1}, \mathrm{~T}_{2}, \mathrm{~T}_{3}, \ldots, \mathrm{T}_{\mathrm{M}}\right\}$, dimana setiap $\mathrm{T}_{\mathrm{i}}$ adalah vektor dari dimensi $\mathrm{N}$ dan $\mathrm{M}$ adalah jumlah citra wajah dalam training set.

Rata-rata dari citra wajah (average face) tersebut adalah

$$
\Psi=\frac{1}{M} \sum_{i=1}^{M} T_{i}
$$

Dengan mencari selisih rata-rata citra wajah (average face) terhadap masing-masing citra wajah dalam training set, didapat vektor selisih

$$
\begin{gathered}
\left\{\Phi_{1}, \Phi_{2}, \Phi_{3, \ldots} \Phi_{\mathrm{M}}\right\} . \\
\Phi_{i}=T_{i}-\Psi
\end{gathered}
$$

Kovarian antara dua dataset menunjukkan seberapa dekat keduanya berhubungan satu sama lain. Dalam kasus ini, kovarian matrik $\mathrm{C}$ merepresentasikan hubungan antara 2 matrik dan varian yang terdapat dalam dataset.

$$
\mathrm{C}=\mathrm{A} \times \mathrm{A}^{\mathrm{T}}
$$

Dalam hal ini $\mathrm{A}^{\mathrm{T}}$ adalah matrik transpose dari matrik $\mathrm{A}$, dimana $\mathrm{A}$ adalah selisih dari masing-masing citra wajah trainig set dengan rata-rata dari citra wajah (average face).

Kovarian matrik ini adalah matrik yang dapat menghasilkan vektor eigen dan nilai eigen yang kita butuhkan. Tetapi untuk menghitung vektor eigen dan nilai eigen dari matrik kovarian (C) secara keseluruhan adalah tidak praktis dan sangat sukar. Dikarenakan matrik w $\mathrm{x}$ h dari citra wajah diperlakukan sebagai vektor dimensi $\mathrm{N}$, maka dengan melihat rumus matrik kovarian (C) menunjukkan bahwa matrik $\mathrm{C}$ berdimensi $\mathrm{N}^{2}$. Ini menunjukkan matrik kovarian (C) adalah matrik yang sangat besar dan sangat sukar untuk menghitung vektor eigen. Bila dimisalkan gambar yang akan diteliti memiliki ukuran 128 x 128, maka dapat dikatakan bahwa dimensi vektornya adalah 16.384. ini berarti matrik kovarian akan berdimensi $16.384 \mathrm{x}$ 16.384. Mengingat tujuan dari PCA (Principal Component Analysis) adalah untuk mendapat representasi dimensional yang rendah dari training set maka perhitungan terhadap matrik kovarian yang besar harus dihindari. Vektor eigen dan nilai eigen dari matrik kovarian adalah

$$
\mathrm{Cx} \mathrm{U}_{\mathrm{i}}=\lambda_{\mathrm{i}} \mathrm{xU}_{\mathrm{i}}
$$

Dimana $\mathrm{U}_{\mathrm{i}}$ adalah vektor eigen dari citra wajah dalam training set yang bersangkutan dan $\lambda_{\mathrm{i}}$ adalah nilai eigen dari citra wajah dalam training set yang bersangkutan.

Cara yang diajukan oleh Turk dan Pentland untuk masalah ini adalah dengan mengambil setiap vektor citra $\Phi_{i}$ dan menempatkannya pada setiap kolom di matrik A.

$$
\mathrm{A}=\left\{\Phi_{1}, \Phi_{2}, \Phi_{3, \ldots} \Phi_{\mathrm{M}}\right\}
$$

Dengan menggunakan trik matematika agar mudah untuk menghitung vektor eigen dan nilai eigen dari matrik $A$, kita misalkan $L=A^{T} x A$. $L$ adalah matrik dengan dimensi $\mathrm{M} \times \mathrm{M}$ dan $\mathrm{M}$ lebih kecil dari $\mathrm{N}$, sehingga vektor eigen dan nilai eigen dari matrik tersebut lebih mudah dihitung. Untuk mendapat vektor eigen dan nilai eigen dari matrik kovarian (C) dipecahkan melalui persamaan berikut

$$
\begin{gathered}
L \times V_{i}=d_{i} \times V_{i} \\
A^{T} \times A \times V_{i}=d_{i} \times V_{i} \\
A \times A^{T} \times A \times V_{i}=d_{i} \times A \times V_{i} \\
C \times A \times V_{i}=d_{i} \times A \times V_{i}
\end{gathered}
$$

Berdasarkan persamaan diatas vektor eigen dan nilai eigen dari matrik kovarian adalah $\mathrm{U}_{\mathrm{i}}=\mathrm{A} \times \mathrm{V}_{\mathrm{i}}$ dan $\lambda_{\mathrm{i}}=\mathrm{d}_{\mathrm{i}}$ sehingga akan didapatkan vektor eigen dan nilai 
eigen sebanyak $M$ dari matrik L. $U_{i}$ merupakan representasi Eigenface, tetapi kita hanya membutuhkan M' Eigenface yang mana jumlahnya lebih kecil daripada M dengan memilih berdasarkan nilai eigen yang terbesar. Kemudian setiap citra wajah dalam training set di proyeksikan dengan M' kedalam eigenspace dengan persamaan

$$
\begin{aligned}
& \mathrm{w}_{\mathrm{k}}=\mathrm{U}^{\mathrm{T}} \times \Phi_{\mathrm{i}} \\
& 1 \leq \mathrm{k} \leq \mathrm{M}, 1 \leq \mathrm{i} \leq \mathrm{M}
\end{aligned}
$$

b. Klasifikasi Citra Wajah Masukan

Untuk menentukan citra wajah masukan adalah citra wajah yang ada dalam database, maka kita menggunakan ruang wajah dalam penentuannya. Sebelum menghitung jarak antara citra wajah masukan dengan citra wajah dalam training set adalah memproyeksikan citra wajah masukan ke dalam eigenspace dengan persamaan sebagai berikut

$$
\mathrm{w}_{\mathrm{n}}=\mathrm{U}^{\mathrm{T}} \mathrm{x}\left(\mathrm{T}_{\mathrm{n}}-\Psi\right)
$$

Dimana $\mathrm{w}_{\mathrm{n}}$ adalah eigenspace untuk citra masukan, $\mathrm{U}^{\mathrm{T}}$ dan $\Psi$ didapatkan dari perhitungan sebelumnya dan $T_{n}$ adalah citra masukan yang sudah dibentuk ke dalam vektor kolom.

Klasifikasi dari citra wajah masukan dilakukan dengan cara membandingkan bobot setiap elemen pada training set terhadap citra wajah masukan. Metoda pola pengenalan standar dapat digunakan untuk mengklasifikasikan citra masukan ke dalam kelas identitas yang diketahui. Metode paling sederhana untuk permasalahan ini adalah dengan metode jarak euklidis (Euclidian distance).

Euclidian distance (jarak euklidis) adalah metode pola yang paling sering digunakan untuk menghitung kesamaan 2 vektor. Jarak euklidis menghitung akar dari kuadrat perbedaan 2 vektor. Rumus dari jarak euklidis sebagai berikut

$$
d_{i j}=\sqrt{\sum_{k=1}^{n}\left(x_{i k}-x_{j k}\right) \cdot\left(x_{i k}-x_{j k}\right)}
$$

Normalized Euclidean Distance, Jarak euklidis ternormalisasi dari dua vektor ciri $\boldsymbol{u}$ dan $v$ adalah:

$$
\bar{d}_{u v}=\sqrt{\sum_{i=1}^{k}\left(\bar{u}_{i}-\bar{v}_{i}\right) \cdot\left(\bar{u}_{i}-\overline{v_{i}}\right)}
$$

Dengan

$$
\overline{u_{i}}=\frac{u_{i}}{\square u \square}, \overline{v_{i}}=\frac{v_{i}}{\square v \square}
$$

$\square v \square$ disebut norm dari $v$ yang dinyatakan sebagai:

$$
\square v \square=\sqrt{\sum_{i=1}^{k} v_{i .} v_{i}}
$$


Semakin kecil skor $\bar{d}_{u v}$ maka semakin mirip kedua fitur yang dicocokkan. Sebaliknya, semakin besar skor $\bar{d}_{u v}$ maka semakin berbeda kedua vektor ciri. Sifat jarak euklidis ternormalisasi adalah bahwa hasilnya berada pada rentang $0 \leq \bar{d}_{u v} \leq 2$. Untuk mengklasifikasikan citra wajah masukan dengan citra wajah dalam training set adalah dengan mencari jarak terkecil dari citra masukan dengan citra wajah dalam training set ke M.

\section{Segmentasi Citra}

Segmentasi adalah proses pembagian sebuah citra kedalam sejumlah bagian atau obyek (Gonzales dan Wintz, 1987). Segmentasi merupakan suatu bagian yang sangat penting dalam analisis citra secara otomatis, sebab pada prosedur ini obyek yang diinginkan akan disadap untuk proses selanjutnya. Algoritma segmentasi didasarkan pada 2 buah karakteristik nilai derajat kecerahan pada citra yaitu: discontinuity dan similarity. Pada item pertama, citra dipisahkan/dibagi atas dasar perubahan yang mencolok dari derajad kecerahannya. Aplikasi yang umum adalah untuk deteksi titik, garis, area, dan sisi citra. Pada kategori kedua, didasarkan atas thresholding, region growing, dan region spiltting and merging. Tiap piksel dalam suatu wilayah mempunyai kesamaan karakteristik atau propeti yang dapat dihitung (computed property), seperti: warna (color), intensitas (intensity), dan tekstur (texture).

Dalam kasus ini digunakan segmentasi citra berdasarkan area tekstur wajah, karena pada pengolahan awal citra hanya ingin mengambil fokus di bagian komposisi wajah inti mulai dari alis hingga dagu.

\section{Principal Component Analysis}

Principal Component Analysis (PCA) merupakan salah satu hasil berharga dari aljabar linear terapan. Prosedur PCA pada dasarnya adalah bertujuan untuk menyederhanakan variabel yang diamati dengan cara menyusutkan (mereduksi) dimensinya. Hal ini dilakukan dengan cara menghilangkan korelasi diantara variabel bebas melalui transformasi variabel bebas asal ke variabel baru yang tidak berkorelasi sama sekali tanpa menghilangkan informasi penting yang ada di dalamnya atau yang biasa disebut dengan principal component. Dengan reduksi ini maka waktu komputasi dapat dikurangi dan kompleksititas dari citra wajah yang tidak perlu dapat dihilangkan. Principal Component Analysis menggunakan vektor-vektor yang disebut dengan eigenvector dan nilai-nilai yang disebut dengan eigenvalue untuk mendapatkan fitur yang paling signifikan pada dataset.

\section{Matlab}

MATLAB adalah sebuah bahasa dengan kemampuan tinggi untuk komputasi teknis. Ia menggabungkan komputasi, visualisasi, dan pemrograman dalam satu kesatuan yang mudah digunakan di mana masalah dan penyelesaiannya diekspresikan dalam notasi matematik yang sudah dikenal. Pemakaian MATLAB meliputi :

- Matematika dan komputasi

- Pengembangan algoritma

- Akuisisi data

- Pemodelan, simulasi dan prototype

- Grafik saintifik dan engineering

- Perluasan pemakaian, seperti graphical user interface (GUI).

MATLAB adalah system interaktif yang mempunyai basis data array yang tidak membutuhkan dimensi. Ini memungkinkan kita dapat menyelesaikan banyak masalah komputasi teknis, khususnya yang berkaitan dengan formulasi matrik dan vector.

Nama MATLAB merupakan singakatn dari matrix labolatory . MATLAB awalnya dibuat untuk memudahkan dalam mengakses software matriks yang telah dikembangkan oleh LINPACK dan EISPACK. Dalam perkembangannya, MATLAB mampu mengintegrasikan beberapa software matriks sebelumnya dalam satu software untuk komputasi matriks. Tidak 
hanya itu, MATLAB juga mampu melakukan komputasi simbolik yang biasa dilakukan oleh MAPLE

\section{Metodologi Penelitian}

Metodologi yang dilakukan dalam penelitian model deteksi wajah adalah sebagai berikut:

a. Melakukan pengumpulan data-data citra wajah yang dibutuhkan dari hasil pemotretan menggunakan alat sensor kamera atau mengumpulkan citra wajah melalui browsing dari internet.

b. Mempelajari buku-buku tentang Pengolahan Citra Digital (Digital Image Processing),Pengenalan Pola (Pattern Recognition) serta literatur - literatur dari internet yang sesuai dengan topik penelitian ini.

c. Melakukan perancangan sistem, diantaranya adalah:

1) Perancangan sistem untuk fase pelatihan (training) berupa normalisasi dan mengekstrak fitur-fitur utama pada beberapa sampel wajah menggunakan algoritma Principal Component Analysis (PCA).

2) Perancangan sistem untuk fase pengujian atau deteksi (detection) berupa normalisasi dan menganalisa citra wajah baru sebagai data input dengan membandingkan fiturfitur utama citra wajah yang telah terbentuk dari hasil fase training.

3) Perancangan sistem secara Graphical User Interface (GUI) agar memudahkan pengguna dalam berdialog atau berinteraksi dengan sistem.

d. Melakukan pengkodean/implementasi sistem menggunakan software Matlab R2009b.

e. Melakukan pengujian (testing) sistem terhadap data sampel citra wajah hasil training dengan data citra wajah baru sebagai data input untuk dideteksi atau pencocokkan pola.

\section{Analisa Sistem Aplikasi}

Sistem Aplikasi yang diusulkan yaitu sebuah sistem yang dapat mencari informasi seseorang dengan masukan berupa citra wajah atau mungkin sketsa wajah orang yang akan dicari informasinya. Dengan citra wajah masukan ini sistem akan mencari sekumpulan orang yang mempunyai wajah yang mirip dengan citra wajah masukan. Ada tidaknya citra wajah masukan pada sekumpulan orang tersebut hanya dapat diketahui dengan pembuktian lebih lanjut, yaitu dengan proses verifikasi atau identifikasi.

\section{Metode Kerja Sistem Aplikasi}

Sistem aplikasi ini dijalankan pada sebuah komputer yang sudah ter-install sistem aplikasi pencarian informasi seseorang dengan masukan citra wajah. Sistem ini terhubung dengan database dan menggunakan sebuah webcam yang dihubungkan pada port USB komputer. Apabila webcam sudah berhasil terhubung maka polisi dapat meng-capture citra wajah seseorang dengan webcam untuk dicari informasinya.

Sistem aplikasi ini berjalan setelah menerima masukan berupa citra masukan yang akan dicari dalam database. Citra masukan pada sistem ini berupa citra wajah. Sistem akan mencari citra wajah dalam database yang mempunyai tingkat kemiripan paling tinggi dengan citra masukan. Keluaran dari sistem ini berupa citra wajah yang terdiri dari beberapa buah citra (28 citra) yang memiliki tingkat kemiripan paling tinggi dengan citra masukan. Kemudian dapat mencari informasi seseorang yang berada dalam kumpulan citra keluaran tersebut.

Ukuran citra dalam database dibatasi, yaitu 100 x 130 piksel sedangkan citra wajah masukan tidak dibatasi, karena akan di resize otomatis oleh sistem. Format untuk suatu citra, baik citra dalam database maupun citra masukan yaitu JPG atau JPEG. Citra wajah dalam database akan dikonversi ke dalam ruang warna beraras keabuan (grayscale). Setelah melakukan konversi ruang warna akan dilakukan tahap pelatihan, berikut adalah langkahlangkah tahap pelatihan: 
1. Ambil suatu set citra pelatihan sebanyak M buah dengan format citra JPG atau JPEG dengan background minimum atau tanpa background sama sekali dengan ukuran yang sama dan dijadikan vektor kolom.

2. Melakukan kalkulasi average face dengan menambahkan seluruh nilai intensitas piksel citra dan membaginya dengan jumlah total citra wajah dalam citra pelatihan.

Average Face $=($ Jumlah vektor citra wajah 1 sampai dengan M) / Jumlah Wajah atau M.

3. Mencari selisih citra wajah terhadap average face, sehingga memperoleh matrik A.

$\mathrm{A}=\mathrm{X}_{\mathrm{i}}-$ Average Face.

Catatan: $X_{\mathrm{i}}$ adalah vektor citra wajah ke-i

4. Membangun matrik L dengan mengoptimalisasi algoritma eigenface.

$\mathrm{L}=\mathrm{A}^{\mathrm{T}} \times \mathrm{A}$

Catatan: dalam hal ini variabel $\mathrm{A}$ sama dengan matrik $\mathrm{A}$ di atas, $\mathrm{A}^{\mathrm{T}}$ adalah matrik transpose dari matrik A.

5. Menghitung vektor eigen dan nilai eigen dari matrik L.

6. Mengurutkan vektor eigen L dengan dengan urutan nilai eigen terbesar ke nilai eigen terkecil dan mengambil M' vektor eigen dengan nilai eigen terbesar.

7. Membangun eigenface dengan mengalikan matrik L dengan matrik A.

8. Memproyeksikan setiap wajah dalam citra pelatihan ke dalam ruang wajah.

Untuk proses pencarian, citra wajah masukan akan dikonversi ke dalam ruang warna beraras keabuan (contoh image menggunakan background green). Setelah melakukan konversi ruang warna akan dilakukan tahap pencarian, dengan mencocokkan citra wajah masukan dengan setiap citra wajah dalam citra pelatihan

\section{Hasil dan Pembahasan}

Untuk proses pencarian, citra wajah masukan akan dikonversi ke dalam ruang warna beraras keabuan (contoh image menggunakan background green). Setelah melakukan konversi ruang warna akan dilakukan tahap pencarian, dengan mencocokkan citra wajah masukan dengan setiap citra wajah dalam citra pelatihan. Untuk melakukan proses pencarian diperlukan 2 data set, yaitu:

\section{Training set (citra pelatihan)}

Sub menu ini berguna untuk membaca citra training ada, yang selanjutnya akan diproses guna mendapatkan fitur-fitur dari citra wajah training yang akan disimpan dalam folder training yang selanjutnya akan digunakan dalam proses recognizing.

Untuk menguji keberhasilan perangkat lunak yang dibuat, maka penulis mencoba dengan beberapa contoh citra training yang dipergunakan dalam pelatihan. Training set merupakan sekumpulan citra wajah yang terdapat dalam database, proses training set dilakukan dengan tahapan-tahapan pelatihan di bawah. Operasi training set dilakukan dengan urutan sebagai berikut:
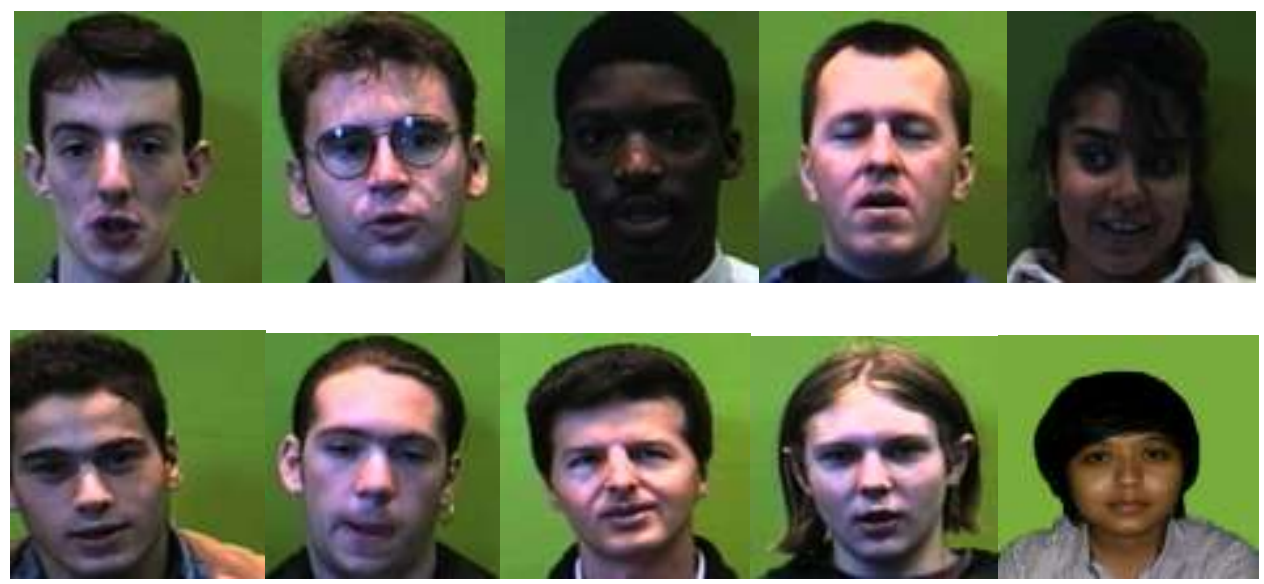

Gambar 1. Fitur Citra Wajah Training Set 
2. Testing set (Citra Pengujian).

Input testing (masukan pengujian) dipilih dari sisa citra input yang tidak disertakan (digunakan) pada inputan training.

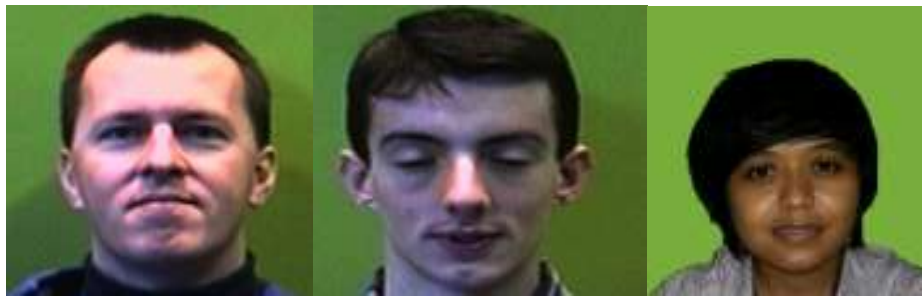

Gambar 2. Pemilihan Citra Wajah Testing Set

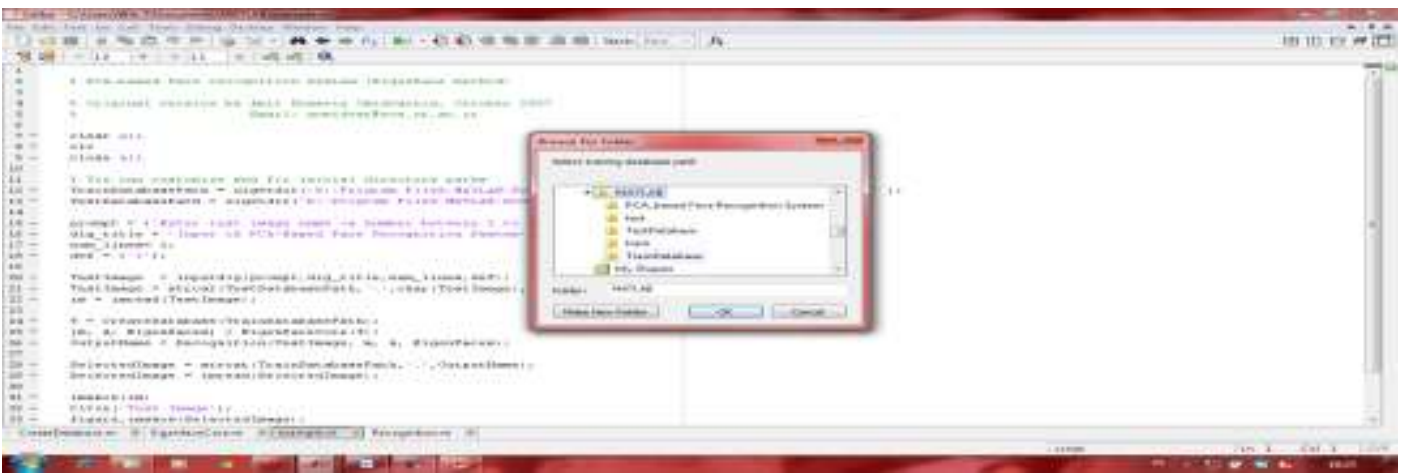

Gambar 3. Train Database

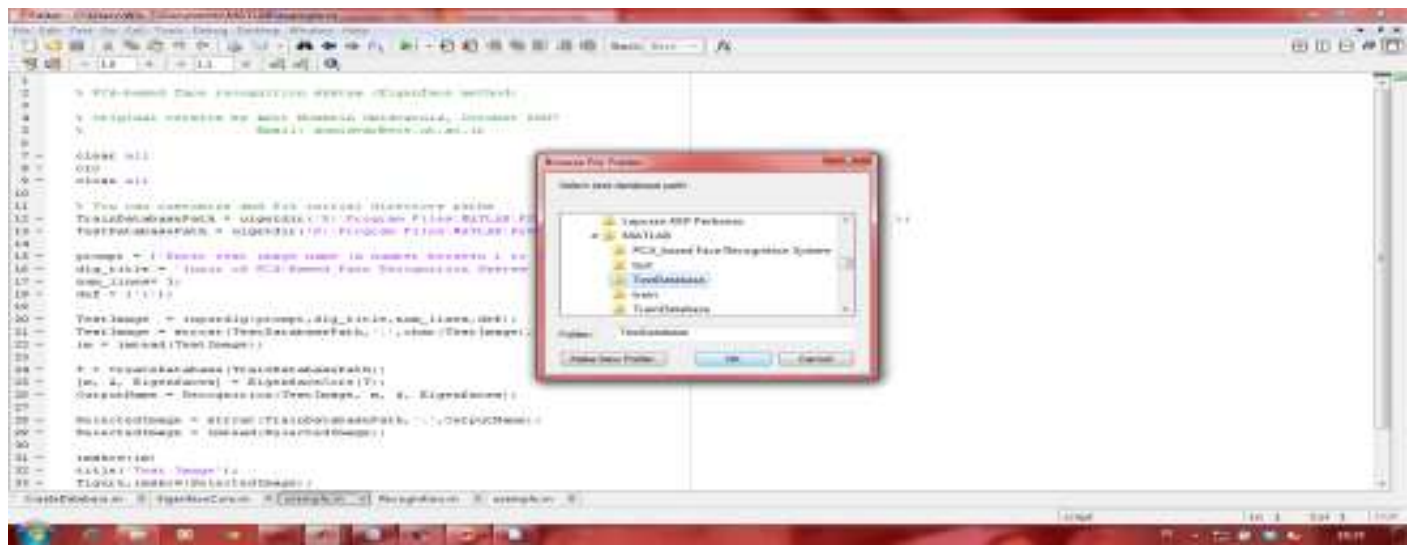

Gambar 4.Test Database

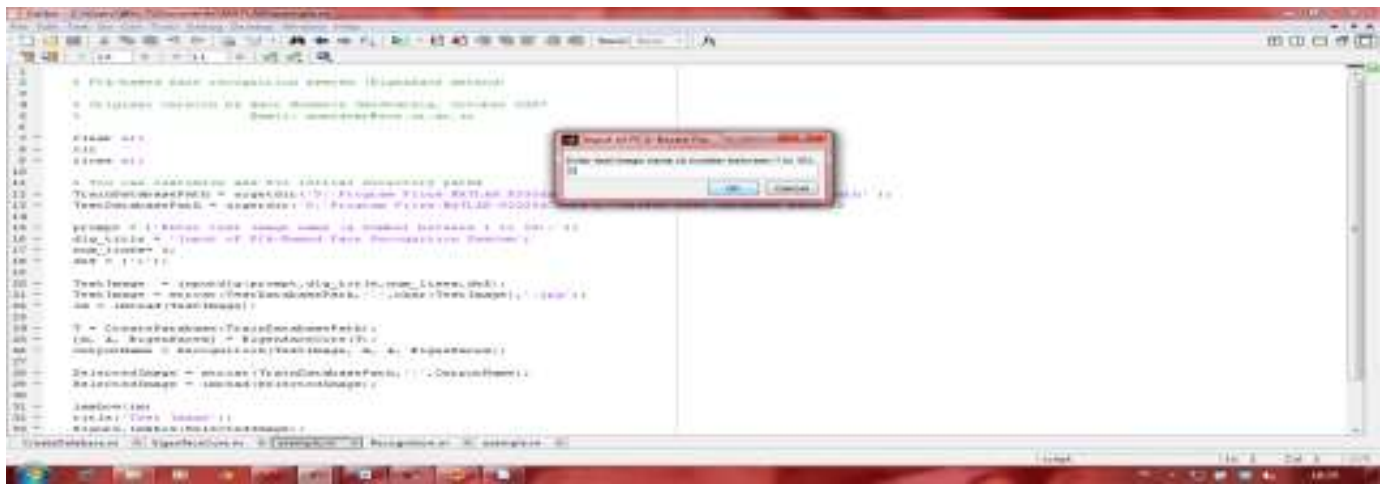

Gambar 5. Input Test Image 


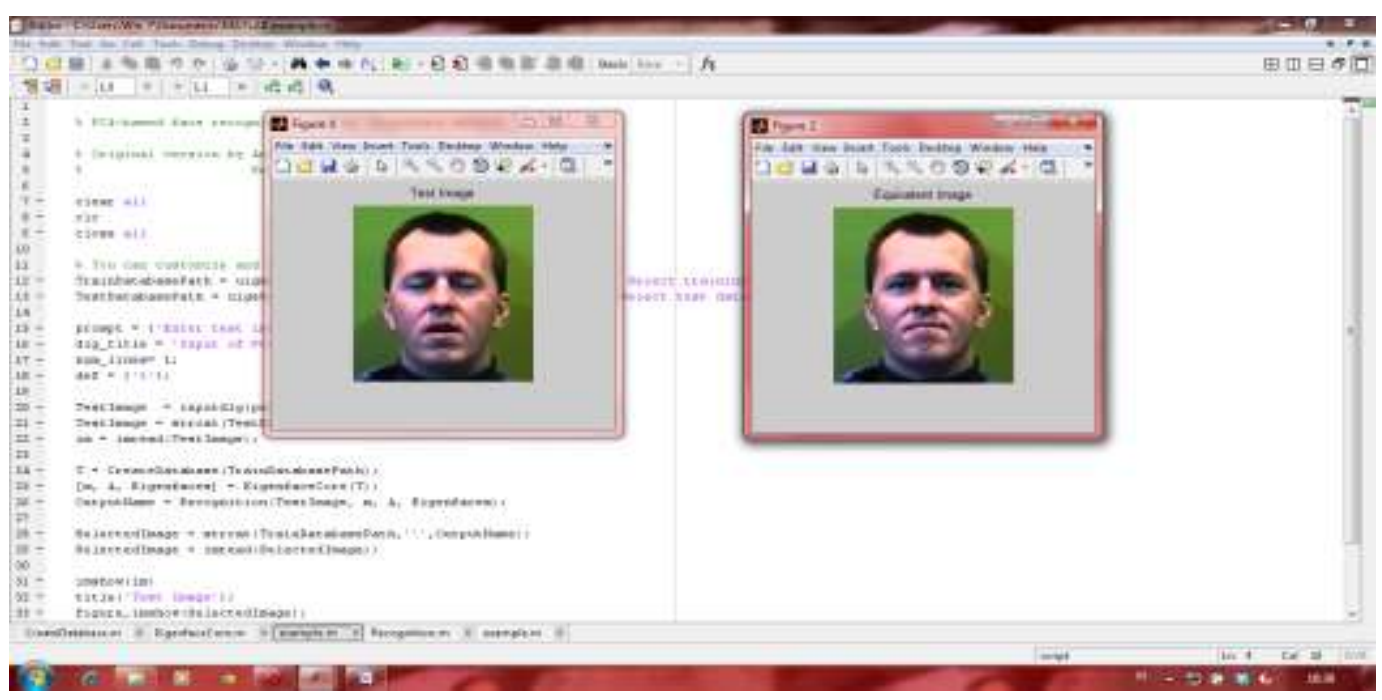

Gambar 6. Hasil Kemiripan Image

\section{Simpulan dan Saran \\ Simpulan}

Berdasarkan uji coba sistem aplikasi yang telah dibangun maka dapat ditarik beberapa kesimpulan sebagai berikut:

1. Aplikasi yang dibuat mendukung pengukuran dan analisis ciri biologi seseorang, sehingga memberikan informasi yang saling terkait merujuk karakteristik atau bagian tertentu pada seseorang sebagai proses pengenalan (otensifikasi). Inputan yang diperlukan dalam aplikasi ini adalah berupa gambar wajah dengan ukuran dan resolusi yang sama dalam bentuk citra skala abu-abu beserta inputan class. Class yang sama untuk wajah orang yang sama, untuk mengenali wajah seseorang dalam berbagai ekspresi dan posisi.

2. Terdapat beberapa faktor yang mempengaruhi hasil pengenalan yaitu posisi citra masukan, tingkat kecerahan, dan kemiripan nilai eigenface.

Waktu pencarian informasi seorang tindak pidana menjadi lebih cepat, dan sistem menampilkan beberapa citra wajah yang mempunyai kemiripan paling tinggi dengan citra masukan, sehingga lebih mudah untuk mencarinya.

3. Hasil pencarian dipengaruhi oleh faktor cahaya, sudut, dan lainnya.

4. Aplikasi yang dibuat mendukung pengukuran dan analisis ciri biologi seseorang, sehingga memberikan informasi yang saling terkait merujuk karakteristik atau bagian tertentu pada seseorang sebagai proses pengenalan (otensifikasi). Inputan yang diperlukan dalam aplikasi ini adalah berupa gambar wajah dengan ukuran dan resolusi yang sama dalam bentuk citra skala abu-abu beserta inputan class. Class yang sama untuk wajah orang yang sama, untuk mengenali wajah seseorang dalam berbagai ekspresi dan posisi.

\section{Saran}

1. Untuk mendapatkan hasil pengenalan yang lebih baik kedepannya, sebaiknya dapat dipertimbangkan menggunakan algoritma preprocessing lain yang dapat mendeteksi wajah dengan segala posisi bukan hanya berdasarkan ekspresi saja.

2. Kemampuan sistem ini sebenarnya masih jauh dari sempurna, terlebih karena tidak adanya modul deteksi wajah untuk sebuah citra. Oleh karena itu kedepannya disarankan untuk membuat modul ini. Sedangkan untuk kemampuan akurasi yang tidak terlalu bagus dikarenakan faktor cahaya, sudut, dan lainnya, perlu dibuat modul normalisasi yang lain, sehingga sistem ini dapat memperoleh tingkat akurasi yang lebih baik. 
3. Perlu dilakukan penelitian tentang pengenalan yang menyangkut emosi seseorang (senang, marah, sedih, takut, berani, kaget, dan lain-lain), yang dapat diketahui dari raut wajah seseorang.

\section{Daftar Pustaka}

Arymurthy, A., Murni., \& Setiawan, S. (1992). Pengantar Pengolahan Citra, Jakarta: Elex Media Komputindo.

Bulhumeur, P.N., Hespanha, J.P., \& Kriegman, D.J. (1997). Eigenfaces vs Fisherfaces Recognition Using Class Specific Linear Projection. IEEE Transactions on Pattern Analysis and Machine Intelligent.

Gerad, B., \& Maurice C. (2006). Digital Signal and Image Processing using Matlab. ISTE Ltd. Newport Beach. USA.

PCA Based Face Recognition System. (2008). Diakses dari website: http://www.mathworks.com/matlabcentral/fileexchange/17032.

Wijaya, dkk. (2007). Pengolahan Citra Digital Menggunakan Matlab. Bandung: Informatika.

Yambor, W.S. (2000). Analysis of PCA Based and Fisher Discriminant-Based Image Recognition Algorithms. Tesis of Master. Colorado State University. 